\title{
Regional standards of membership and enlargement in the EU and ASEAN
}

\author{
Kilian Spandler ${ }^{1}$
}

Published online: 21 March 2018

(C) The Author(s) 2018

\begin{abstract}
For regional organizations (ROs) as geographically defined entities, questions of membership often raise moral questions about the very foundations of regional identity. To date, comparative approaches to the role of norms in the politics of RO enlargement are a missing piece in the regionalism literature. This paper assumes that enlargement practices are shaped by discourses about legitimate actorness. Drawing on the concept of "standards of civilization," I argue that prospective RO members are judged against a set of norms - the standard of membership — which constitute basic ideas about the identity of the regional international society. As evidence from the Spanish and Greek accession to the European Community and the accession of Myanmar and Cambodia to ASEAN shows, this standard is not a static catalogue of cultural values, as existing accounts suggest, but develops in response to accession requests which trigger normative crises among the existing member states. In such situations, RO actors may argue for the inclusion of new norms in the standard of membership by drawing on "cognitive priors". Enlargement processes thus reveal a dialectical relation between regional norms and boundary-drawing; while a regional standard of membership informs the redefinition of an RO's boundaries, the accession of new candidates also transforms that very standard.
\end{abstract}

\section{Introduction}

The discussion about the finality of the European Union's (EU) borders is back with a vengeance. The heated debates about Brexit, Turkey's accession process and a potential suspension of Hungary's and Poland's membership rights are glaring reminders that questions of membership are closely linked to different understandings of regional identity and normative considerations. What is true for the EU applies to regional organizations (ROs) in general; the definition of their boundaries is an existential and

Kilian Spandler

kilian.spandler@gu.se

1 School of Global Studies, University of Gothenburg, Box 700, 40530 Gothenburg, Sweden 
inherently problematic and political exercise (Thomas 2017). Decisions over membership are inherently linked to common understanding not just about the geographical extension of a region but also "what it means to be," say, a European or Southeast Asian state. While such questions may be pushed to the background or suppressed entirely during much of an RO's existence, they become manifest and subject to debate in critical moments when concrete decisions about membership must be taken.

While Brexit shows that the redrawing of boundaries can also come in the form of a member state leaving an RO, a cursory review of membership development shows that most ROs have admitted more new members than they lost established ones. Despite the obvious importance of the social construction of boundaries for this process, comparative regionalism scholarship has hardly produced any comparative studies on the role of ideational factors in the politics of RO enlargement. The existing single-case studies of individual organizations convincingly make the case that norms matter but display a certain equivocality regarding the significance of normative change and the mechanisms linking norms to enlargement practices. This article attempts to close this gap by comparing the discourses surrounding normative crises in the enlargement processes of the EUor, to be more exact: its predecessor, the European Communities (EC) — on the one hand and the Association of Southeast Asian Nations (ASEAN) on the other. In these crises, the established members faced the problem of dealing with the prospect of accession by states whose domestic situations had uncertain or negative implications for the RO and challenged tacit normative convictions. Their reaction to these challenges diverged. While the EU formalized the requirement of democratic institutions as an entry condition, ASEAN developed a norm prescribing domestic political stability as a criterion for membership. The article makes sense of these differences by examining the intricate relationship between enlargement practices and regional norms. On the one hand, normative considerations shape enlargement practices. On the other hand, these ideas are not stable but can be actively reshaped, especially when membership requests trigger normative crises.

The following section reviews the literature on the role of ideational factors in RO enlargement. Based on this engagement, the Section "Regional standards of membership" addresses open questions in this literature by adapting the concept of "standards of civilization" developed in the English School of International Relations for the purpose of cross-regional comparison. I then analyze the development of what I call regional standards of membership in Europe and Southeast Asia in the context of two concrete enlargement processes of the EC/EU and ASEAN. The discourses surrounding the membership applications and subsequent accessions of Spain and Greece on the one hand and Myanmar and Cambodia on the other demonstrate that the development of standards of membership depends on existing normative reference points, or "cognitive priors."

\section{Ideational factors in RO enlargement- the literature}

Although comparative regionalism - understood as an approach that relies on comparative methods in order to shed light on common trends in and differences between regionalisms around the world - is a budding field of research (Börzel and Risse 2016), it has so far largely neglected RO enlargement as an object of study. ${ }^{1}$ Consequently, an

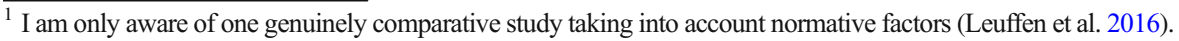


inquiry into the normative dimension of enlargement needs to start from regional integration scholarship with a more idiographic outlook. The core assumption of this literature is that ROs embody regional communities, which share certain core norms and values (Thomas 2017). ${ }^{2}$ While many scholars working within a constructivist paradigm agree on this tenet, they see different implications for RO enlargement. One group concludes that only those states will be considered as potential new members who adhere to regional core norms and values. A major example is the "liberal community hypothesis" (LCT), which holds that established EU member states judged accession candidates based on whether they subscribed to liberal human rights in their domestic political and social order, as well as to peaceful dispute settlement and multilateralism in their external relations (Schimmelfennig 2005a, b; 2016). For ASEAN, Nesadurai (2006, 202-203) argues that the accession of the Indochinese states was made possible by normative convergence on the principle of market liberalism as a provider of growth and social stability.

The second group of researchers concerned with community norms has emphasized the use of enlargement as a means to proactively extend the reach of these norms beyond the formal boundaries of their RO. For example, it has been argued that admitting new members and creating institutional frameworks such as the ASEAN Regional Forum was a way for the original ASEAN member states to socialize their neighbors into the norms of the "ASEAN Way" of regional cooperation, i.e., essentially an exercise in security-community building (Acharya 2001; Amer 1999; Anwar 2001, 30-33). In the European case, this line of argument is represented in the "Europeanization" literature (O'Brennan 2016; Sedelmeier 2011), which sees the use of conditionality in the EU's enlargement and association processes as a strategic instrument to export its institutional order into its periphery. From this perspective, norms are ultimately a form of power through the incentive of institutional absorption (cf. Manners 2002), independent of whether the neighboring states eventually reach full membership or not.

For students of $\mathrm{RO}$ enlargement, these approaches provide valuable insights into the role of ideational factors. At the same time, they are characterized by two shortcomings. First, while the literature on identity politics and rhetoric in RO enlargement emphasizes the malleable nature of ideas about regional self and other (Fierke and Wiener 2005), scholars focusing on regional community norms have not problematized the notion of regional community, presenting it instead as static and given. Schimmelfennig's examination of the LCT, for example, simply assumes that liberal human rights, peaceful dispute settlement, and multilateralism form the normative fundament upon which the European integration project is constructed, and focuses on applicants' compliance to explain their accession. To be sure, his conception of community values is a plausible methodological choice given his interest in hypothesistesting. The downsides of this move are that the conception of community norms is weakly grounded in empirical observation and that the question how actors constructed and reproduced these norms over time remains unanswered. As Thomas (2006; see also

\footnotetext{
The literature on regional communities is connected to but distinct from approaches focusing on the politics of regional identity-building and its role in enlargement. This strand argues that the admission or rejection of new members is influenced by a language distinguishing insiders from outsiders, and that rhetorical appeals to regional concepts and common identities may be used strategically by members and applicants to elicit beneficial enlargement decisions (Acharya 2010; Chin 1997; Fierke and Wiener 2005; Schimmelfennig 2005b; Sjursen 2002).
} 
Wiener 2004, 203) points out, certain seemingly primordial elements of the EU's catalogue of norms were not constitutive of its foundation but only developed in the course of enlargement processes, which are often highly politicized and contested.

What is more, a static or essentialist conception of regional community without empirical grounding also makes the concept inept for cross-regional comparison. For example, according to Stivachtis (2008, 76-77), international organizations judge prospective members against democratic principles. Although he traces the emergence of this idea historically, his examination overstates the global consensus on liberal democracy and is biased towards international organizations of Western coloring. Liberal democratic standards are hardly a cornerstone of regional identity in some other regions, including Southeast Asia. To account for the dynamic and political character of normative community standards, researchers need to move away from the LCT's statist approach focusing on compliance to a social practice perspective, which puts the processes of discursive reproduction and change at the center of analysis (Thomas 2017; Wiener 2004).

The second open question concerns the logic of action through which ideational factors and enlargement practices are linked. While some authors stress the constitutive character of discourses about identity and norms as reproducing understandings about legitimate membership in and the boundaries of an RO (Chin 1997; Tan 2013), others see them as instruments to ensure behavior which is deemed beneficial for its members (Schimmelfennig 2005b; Sedelmeier 2011). Accordingly, enlargement practices are either the result of changed patterns in the self-other distinctions of existing members or in their utility calculations. While some researchers may take the position that locating oneself in this dyad is ultimately a matter of meta-theoretical commitment, I would argue that, in order to reach a deep understanding of enlargement practices, both possibilities must be taken into account and neither should be excluded a priori (Sjursen 2002). If the literature on RO enlargement is to clear up its equivocal treatment of norms, research must therefore illuminate the dynamic relationship between enlargement practices and regional norms and identity. In the following section, I will outline how an adaptation of the concept of "standards of civilization" can help us do so.

\section{Regional standards of membership}

The concept of the "standard of civilization" gained prominence in international relations through Gong's (1984) study on the entry of non-Western states into the originally European international society in the late nineteenth and early twentieth centuries. In his definition, "a standard of civilization is an expression of the assumptions, tacit and explicit, used to distinguish those that belong to a particular society from those that do not" (Gong 1984, 3). In an international context, a standard of civilization contains intersubjectively shared assumptions about the qualities an actor must possess, or the kind of conduct it should engage in or refrain from, in order to be counted as a legitimate member of the international society in question. ${ }^{3}$ This understanding has its intellectual

\footnotetext{
${ }^{3}$ According to Gong, the guarantee of basic rights, internal sovereignty and a monopoly of violence, adherence to international law and rule of law, the fulfillment of the acknowledged obligations of diplomacy and adherence to generally accepted international norms were the essential elements of the historical European standard of civilization.
} 
roots in the English School's argument that inter- and transnational practices are governed by international institutions which express implicitly or explicitly shared principles and norms. ${ }^{4}$ Despite being a contentious concept, three core features make the "standard of civilization" instructive for a comparative analysis of RO enlargement processes.

First, the historic "standard of civilization" drove institutional boundary-drawing, as it invoked a distinction between "civilized" group members from "uncivilized" outsiders (Gong 1984, 5). Since principles and norms concerning legitimate membership and conduct influence the shape of international regimes and organizations (Spandler 2015), the distinction can legitimize a variety of institutional or legal arrangements which formalize these boundaries - ranging from unequal treaties or mandate systems (Gong 1984, 66-69) to the formal enlargement practices of ROs, as several authors have noticed for the EU case (Behr 2007; Stivachtis 2008).

Second, despite an inherent tendency of European states to project the "standard of civilization" as a direct manifestation of deep-seated cultural practices, its content and degree of formalization changed in critical times. As Gong (1984, 27; see also Bull and Watson 1984; Fidler 2001) illustrates, contact with "outsiders" such as Japan was a major stimulus for change, as it prompted Europeans to reflect on the implications for their traditions of international law: “[...] the standard of 'civilization' was gradually articulated in response to the questions which arose from Europe's sustained contact with increasing numbers of non-European countries." Applied to comparative RO enlargement research, this makes an empirical reconstruction of membership standards by interpreting historical sources such as treaties and writings of international lawyers necessary. Several authors have in fact used the concept as an analytical tool to trace the evolution of constitutive norms in historically or geographically specific international societies (e.g., Donnelly 1998; Fidler 2001; Stivachtis 2008; Zhang 2014). These works avoid culturalistic essentialization by highlighting the dynamic, contested, and partially contingent nature of norms. However, while standards can change, this does not mean that any norm may become part of a specific standard at any given time. Usually, their gradual formulation relies on certain "cognitive priors" (for discussions of the concept, see Beeson and Diez, this volume, as well as Acharya 2009), i.e., existing discursive concepts, narratives, or normative convictions that serve as discursive reference points for the construction of an explicit standard. In Gong's case, the ideas of a common Christianity and its civilizing mission provided such a narrative. A comparison of these preconditions situates the norm dynamics surrounding the politics of RO enlargement in their respective regional context and accounts for path-dependence in their development.

Third, the standard was at the same time a constitutive element of an international society in the sense that its members recognized one another by committing to its basic norms, and an instrument of disciplining power by means of setting legal or quasi-legal entry conditions. Gong shows how the encounter with non-European political communities triggered a process through which the Europeans redefined themselves as a community constituted by sovereign nation-states. On the other hand, the standard was also used to project and impose a specific idea of international order, to justify unequal treaties, limit access to decision-making processes: in short, to exercise power

\footnotetext{
$\overline{4}$ Topical introductions to the English School's main concepts - including international society - and debates can be found in Buzan (2014), and Navari and Green (2014).
} 
on the emerging global periphery through the incentive of membership (Gong 1984, 8, 56; see also Keene 2002). Following the via media between constitutive and interestbased theorizing which is characteristic of the English School, Gong's work shows that the question of how community norms and boundary-drawing practices are relatedwhether a constitutive or instrumental logic applies - is not an either-or question. Norms are both markers of identity and can be used as instruments to realize state interests. This idea helps overcome the ontological divide in existing accounts of enlargement.

Distilling the main points from this discussion, the analytical framework of this article sees RO enlargement practices - which comprise the formalization of entry conditions and accession procedures (Leuffen et al. 2016) as well as concrete decisions over membership applications and the resulting treaties - as a process of boundarydrawing which is connected to discourses about regional norms of rightful membership. While the notion of a "standard of civilization" is attuned to a critical analysis of power effects because it points to the mechanisms of inclusion and exclusion by reference to a performatively constructed normative consensus (Stroikos 2014), it also comes with problematic moralistic undertones and the historical baggage of justifying European colonial practices (Keene 2014). For these reasons, but also because the term "civilization" evokes a wider set of shared cultural ("everyday") practices than the more specifically political ones of ROs, calling these sets of norms a region's standard of membership makes the concept more appropriate for the purpose of cross-regional comparison. The civilizational "version" of the standard is then but a specific manifestation of the general logic of boundary-drawing through normative arguing.

The connection between standards of membership and enlargement is reciprocal and follows different logics of action. On the one hand, the standard of an RO defines the identity of the RO's members (constitutive logic) and provides templates for imposing conceptions of order onto accession candidates (instrumental logic; cf. Stivachtis 2008). On the other hand, enlargement processes can also drive change in the RO's standard of membership, especially in enlargement cases which result in a normative crisis. Such situations include membership applications which challenge certain tacit assumptions about the normative underpinnings of the RO (constitutive logic) or have unfavorable or uncertain political, security, or economic consequences (instrumental logic). In such circumstances, discourses about regional identity and legitimate membership are likely to become politicized, potentially resulting in (a) the formalization of previously latent norms, (b) the obsolescence of old norms, or (c) the development of new ones. In any case, the degree and quality of discursive change will always be conditioned by cognitive priors, i.e., existing ideational patterns constraining the possible trajectory of normative change.

To illustrate how a comparative approach based on this conceptualization provides a deeper understanding of the role of norms in the politics of RO enlargement, the following two sections compare the discourses surrounding specific enlargement processes of two ROs: the accession of Spain and Greece to the EC and ASEAN's admission of Myanmar and Cambodia. While I use official RO documents, media reports, and existing academic literature as sources in both parts, the European case draws to a large extent on Thomas' $(2006,2017)$ extensive empirical analyses. The cases are instructive because they display certain similarities in that domestic turbulence in prospective new members sparked normative crises during which actors challenged and ultimately revised the respective ROs' original standards of 
membership, which had been formulated in geographic rather than substantial terms. Despite these parallels, the discourses resulted in divergent normative innovations. The purpose of the comparison is not to isolate explanatory variables in a most similar case design - there are simply too many potentially relevant factors at play to provide for causal explanation strictu sensu. However, it does make the case that understanding divergent cognitive priors as discursive background conditions provides an instructive interpretive lens when accounting for the different trajectories of enlargement practices.

\section{Admitting Spain and Greece into the EC}

The EC initially did not have very elaborate standard of membership. The Treaty of Rome took a very inclusive approach by opening membership to any European state. This geographical limitation defined the organization as the representative of a regional international society. Apart from that, the enlargement procedures laid down in the Treaty were procedural ${ }^{5}$ rather than substantial and no explicitly political conditions applied.

This rudimentary standard of membership was increasingly contested as the use of Association Agreements with European states raised the question of the EC's relations with autocratic states, and triggered a discourse about the normative foundations of the Community (Thomas 2006, 1191) - a process similar to the development of the nineteenth-century "standard of civilization" in response to Japanese advances. In 1961, plans of Francoist Spain to apply for association became public. Since an agreement would have made possible eventual membership, the prospect met with strong resistance by the European Parliamentary Assembly and civil society actors (Thomas 2006). The Asssembly's Birkelbach Report (1961, Art. 35, my translation), drawn up under the impression of the Spanish issue, argued that "the guaranteed existence of a democratic state structure, in the sense of liberal political organization, is a condition for accession." To justify this assertion, the report invoked the prevalence of democratic institutions in the current member states, arguing that non-democratic states would constitute "a foreign body" in the community (Birkelbach 1961, Art. 24, my translation).

This purported democratic tradition served as a cognitive prior from which a democratic identity of the EC could be constructed (Frowein 1984, 1311-1312; Thomas 2017, 223-224). While some member state governments had initially supported the Spanish initiative, it became increasingly obvious that admitting an autocratic state would contravene tacit assumptions about the EC's identity, even though it had not formally violated any membership conditions. The council eventually gave in to mounting political and public pressure, and decided not to make any commitments to Spanish membership for the time being (Thomas 2006, 1191).

Adding to these dynamics was the coup d état in Greece, an associated state, in 1967. The assumption of power by a military junta was condemned by the EP, which immediately argued for a suspension of the agreement (European Parliament 1967).

\footnotetext{
${ }^{5}$ Upon application, the Commission was to draw up a recommendation, based on which the Council would make a formal decision. The terms of the agreement were to be negotiated between the member states and the applicant (Treaty Establishing the European Economic Community 1957, Art. 273).
} 
Under the impression of the EP s strong rhetoric, the commission effectively put the agreement, and with it the prospect of Greek membership, on hold "so long as democratic and parliamentary structures have not been reestablished in Greece." (cited in European Commission 1975). The explicit application of conditionality with respect to democratic government is notable, since democracy was neither an explicit part of the accession criteria in the Treaty of Rome, nor of the Greek association agreement. Normative considerations thus overrode existing formal-legal rules, although the lack of a legal basis also led the EC to merely limit the application of the agreement, rather than suspending it entirely as demanded by the EP's (Katselli Proukaki 2010, 119-120).

The Greek question was resolved after the restoration of democratic rule in 1974. The EC reactivated the association agreement and eventually assented to the new government's application to become a member of the organization. However, the Spanish and Greek episodes had triggered a normative crisis in the community, resulting in a discourse about the constitutive foundations of integration. Consequently, the EC's standard of membership came to include democratic principles which had hitherto been considered questions of domestic political order, and thus beyond the realm of community politics.

This change in the standard of membership had a profound influence on subsequent enlargement practices. In 1977, Spain and Portugal, another formerly authoritarian state, applied for membership. Indirectly responding to these requests, the European Council s Declaration on Democracy declared the respect and maintenance of democracy and human rights "essential elements of membership of the EC" (European Council 1978). The two applicants were only admitted after the Commission had confirmed their democratic credentials. When the European Commission delivered a second opinion on Greek accession, it adopted this wording and justified it by emphasizing that "the principles of pluralist democracy and respect for human rights form part of the common heritage of the peoples of the States brought together in the European Communities" (European Commission 1979).

Subsequent EC documents continued along this incremental path of explicating and formalizing the requirement of democratic government, culminating in the Copenhagen criteria, which explicitly count liberal democratic institutions among the membership conditions (Frowein 1984, 1316-1318). While it transformed the internal identity of the $\mathrm{EC}$, the formalization of the standard of membership to include democratic principles and the subsequent institutionalization practices also exerted a strong disciplining power upon potential new members, thus echoing the logic of the original standard of civilization in the nineteenth century with its intrusive logic. By having them subscribe to democratic norms, the EC's standard of membership socialized new members into an identity that reinforced the community norms.

\section{Myanmar, Cambodia and ASEAN's anti-coup norm}

In contrast to the EC, ASEAN s founding document - the Bangkok Declaration (ASEAN 1967) — makes accession dependent on the adherence to specific principles and practices, including multilateralism, international law, and peaceful dispute settlement, as well as non-interference and national self-determination. However, in substance, these normative foundations do not reflect a regionally specific standard, as they 
are also endorsed in the UN Charter. The only more restrictive criterion spelled out in the declaration was "that the Association is open for participation to all States in the South-East Asian Region". Like in the EU case, the initial standard of membership was effectively geographical rather than substantial. ${ }^{6}$ If ASEAN's membership remained largely unchanged until the $1990 \mathrm{~s},{ }^{7}$ this was not because other states failed to meet its criteria but rather because of Cold War divides and a lack of interest among its neighbors, whose neutralist or isolationist foreign policy stance militated against participation in an RO they saw as pro-Western (Anwar 2001, 27-28; Chin 1997, 67; Narine 2002, 40).

The end of the Cold War brought about a rapprochement between Vietnam and ASEAN and put an end to Vietnam's occupation of Cambodia, where general elections led to the formation of a coalition government in 1993 (Amer 1999, 1037; Chin 1997, 7-8). These changes in the regional order sparked a debate about ASEAN's boundaries. Pointing to potential economic benefits and unearthing the aim of uniting all of Southeast Asia as an ostensibly constitutive purpose of ASEAN, officials from several member states argued for enlargement towards Indochina and Myanmar (Choo 1993; Business Times Singapore 1993). Seeing the resolution of the Cambodian issue as a historic opportunity, Indonesian Foreign Minister Ali Alatas (1991) claimed "we will go back to our original blueprint: Southeast Asia must become one, not a region of two polarized mini-blocs."

There was thus a widespread openness to the idea of an "ASEAN of ten" by the end of 1993. The question was on what conditions this objective should be achieved. Measured against the existing inclusive standard of membership, the states of Indochina and Myanmar all qualified for accession. However, enlargement had uncertain and potentially negative effects on the existing member states, and it questioned certain tacit assumptions about its identity. Admitting several economically weak, politically unstable and partly communist states was demanding for a club of essentially pro-market and historically anti-communist states. In this normative crisis, the idea of introducing stronger conditionality soon entered the regional discourse. Thai and Singaporean officials took a rather demanding stance towards the accession candidates, especially regarding economic reforms, which they saw as vital to fostering regional stability (Goh 1991; Jayanama 1991). However, representatives of the other member states mostly argued for quick and unconditional accession (Isberto 1994), and in July 1994, ASEAN's foreign ministers signaled their readiness to admit Vietnam as ASEAN's seventh member state.

Next on the enlargement schedule were Cambodia, Laos, and Myanmar. Initially, the latter seemed to be the most problematic due to its repressive regime. When the military junta's crackdown on the opposition in 1996 and 1997 sparked international criticism, a regional debate ensued about how assertive the organization should be in its criticism of domestic practices and whether liberal democratic standards, specifically respect for human rights, should be an entry condition (Acharya 2001, 111-112). The foreign ministers of Malaysia and Thailand publicly put Myanmar's planned accession to

\footnotetext{
${ }^{6}$ Of course, the definition of geographical boundaries is always subject to political contestation and strategic calculation (Acharya 2010; Emmerson 1984). In Southeast Asia, any rhetorical inclusiveness was thwarted by Cold War security practices, which effectively drew a dividing line through the region.

${ }^{7}$ The exception is Brunei's accession in 1985.
} 
ASEAN by 1997 in doubt, arguing that the leadership must first move ahead with democratization (Chin 1997; Narine 2002, 115-116; Stewart 1997).

However, these assertions never became a consensual view of ASEAN governments, let alone an official ASEAN position. Liberal democracy did not become a part of ASEAN's standard of membership and Myanmar was admitted alongside Laos in 1997. The reasons for this were of course manifold and included economic calculations, the fear that Myanmar might spin too far into the Chinese orbit of influence, misgivings about Western meddling and a wariness on the part of the non-democratic ASEAN states about the potential consequences of rejecting Myanmar for their own regime security (Weatherbee 2015, 93-95). As far as the normative background against which the admission could be justified is concerned, however, regional cognitive priors were crucial. Unlike the EC, ASEAN discourse did not build on a common democratic history, and the historically strong normative commitment to non-interference in domestic affairs was a key reference point in the debates. Singapore's Prime Minister Goh justified the permissive attitude to Myanmar by asserting that "the internal situation of a country is that country s concern," and Philippine President Fidel Ramos argued that "as far as the internal politics within each country, well, we did not begin Asean by examining that and excluding those that had a different system from ours" (both cited in Khandeparkar 1997).

Somewhat surprisingly, it was not Myanmar's but Cambodia's membership application which had the most profound effect on ASEAN's standard of membership. Originally, Cambodia was to accede alongside Laos and Myanmar. However, on July 5th 1997, just weeks before the planned admission, violent conflict broke out between supporters of the First and Second Prime Minister, Prince Ranariddh and Hun Sen. The clashes resulted in the ousting of Ranariddh, who temporarily fled the country, the takeover of governmental control by Hun Sen, and the suspension of constitutional bodies such as the senate. In an urgently convened meeting on July 10th, the ASEAN foreign ministers agreed to delay Cambodia's entry (ASEAN 1997a).

This decision stood in stark contrast to the statements by Goh and Ramos made only a couple of weeks earlier. How could the organization justify its decision after its acquiescence regarding Myanmar? An examination of the documents related to the Cambodian crisis shows that the member states' criticism focused not on liberal democratic standards but on the instability of the domestic political order and ensuing security threats. The meeting of the ASEAN Standing Committee just 3 days after the coup produced a statement deploring its impact on the well-being of the population:

ASEAN is dismayed by and deeply regrets the unfortunate turn of events in Cambodia, resulting in the loss of innocent lives, both of Cambodian citizens and foreigners. ASEAN calls for an immediate ceasefire. ASEAN also calls upon the Government of Cambodia to take immediate steps to ensure the safety of foreign nationals and provide protection to their properties in that country. ASEAN further calls on the two co-Prime Ministers, the 1st Prime Minister Prince Ranariddh and the 2nd Prime Minister Hun Sen, to resolve their differences peacefully. (cited in Severino 2006, 58).

In subsequent statements, ASEAN officials described the peaceful resolution of the conflict and the return to constitutional politics as a precondition for resuming the 
accession process. Malaysia's Foreign Minister Abdullah, for example, said, "All that we want to see is that the government is in place, the coalition will continue, that the national assembly will not be dissolved" (cited in Ng and Jegathesan 1997, see also ASEAN 1997b; Kassim 1997).

This language refrained from using notions of liberal democracy or human rights, focusing instead on the ability of ASEAN member states to uphold the constitutional order, the rationale being that domestic unrest would eventually threaten the stability of all the regional states (Acharya 2001, 116-117). The notion that "national resilience" in the sense of domestic political stability and "regional resilience" were intertwined had a long tradition among ASEAN countries (Amer 1999, 1033). It had first been officially acknowledged in the Declaration of ASEAN Concord:

The stability of each member state and of the ASEAN region is an essential contribution to international peace and security. Each member state resolves to eliminate threats posed by subversion to its stability, thus strengthening national and ASEAN resilience (ASEAN 1976).

However, the intellectual roots of the idea date back even further, to the visions of political leaders like Aung Sang, Nehru, and Ho Chi Minh, who promoted Asian regionalism as a way of strengthening new found national independence (Acharya 2010, 1005). Initially, ASEAN's appropriation of the national-regional stability nexus did not imply any prescription for the way in which its member states were governed. ASEAN had remained silent on the events surrounding Marcos's rule under martial law and the blatant election fraud in 1986 in the Philippines. It also did not speak out against the coup d'état by the so-called National Peace Keeping Council in Thailand in 1991 (Chalermpalanupap 1999). The proponents of the model thought of the "causal arrow" as flowing mostly from regional cooperation to domestic stability. The concept had represented a security doctrine promoting regional cooperation to prevent the subversion of established regimes, not an intrusive criterion of legitimacy (Acharya 2001; Jorgensen-Dahl 1982, 102).

In the context of the events in Cambodia, however, this cognitive prior provided the basis for constructing domestic political stability as part of the standard of membership. The notion found its expression in a proscription of unconstitutional changes of government. The ASEAN foreign ministers had first expressed this view in 1991, when they demanded "that no Cambodian party should be allowed to seize or retain power through force of arms" (ASEAN 1991). After the 1997 incidents, ASEAN officials clearly depicted the violation of this principle as the primary reason for the delay of Cambodia's entry into the organization. Singapore's Jayakumar (1997) was most explicit about this, counting the imperative of domestic political stability explicitly as one of the "essential principles" of ASEAN cooperation:

Where force is used for an unconstitutional purpose, it is behaviour that ASEAN cannot ignore or condone. [...] Recently, ASEAN reaffirmed this position by its quick, collective arid unequivocal response to the recent events in Cambodia [...]. The use of force to overthrow the established government is a legitimate concern of the international community because it can also pose a threat to regional stability - a matter of concern to ASEAN. 
Indonesia's Alatas (1997) supported Jayakumar s position, describing the events in Cambodia as a challenge to Southeast Asia. Thus, ASEAN leaders reversed the "causal arrow" in the national-regional stability nexus, arguing that domestic unrest in one country might endanger the region as a whole. The description of this link as an ASEAN principle is remarkable, given that historic evidence for a long-standing norm against coups is weak and it could not be derived from its formal enlargement framework. Rather, ASEAN leaders appear to have introduced the normative justification after the fact of Cambodia's temporary exclusion. This mirrors the EU case, where broader normative concerns overrode legal ones in its decision to put the Association Agreement with Greece on ice.

In what may be the clearest sign of recognition of the anti-coup norm, the Cambodian representative ${ }^{8}$ at the July 1997 Ministerial Meeting, Ung Huot (1997), went out of his way to stress "that the operation [...] was not [a] so-called Coup d Etat [as] has been alleged, but a legitimate action to prevent Cambodia from slipping into anarchy and a possible second genocide." Rather than rejecting the validity of the norm, Ung Huot effectively acknowledged it by presenting his faction's actions as a means to prevent domestic instability. As demanded by the ASEAN foreign ministers (ASEAN 1998), elections were held in Cambodia in 1998, which resulted in the formation of a new coalition government. Although representatives from Indonesia, Malaysia, Myanmar, and Vietnam pushed for announcing the accession at the Hanoi Summit in 1998, the Philippines, Singapore, and Thailand insisted to wait until the Cambodian Senate would reconvene, in a clear sign of concern for a sustainable political transition (Singapore Ministry of Foreign Affairs 1998). It was only in 1999 that Cambodia was finally admitted.

While Weatherbee $(2015,96)$ is right in pointing out the respective strategic reasons for the different approaches to Myanmar and Cambodia, the way in which ASEAN officials could justify this divergence normatively was influenced by cognitive priors: the absence of a common democratic identity, the strong non-interference norm, and a strategic doctrine linking domestic and regional resilience. Since 2007, a commitment to "constitutional government" is also legally enshrined as a main principle in the ASEAN Charter. That being said, the watered-down formulation-a draft had explicitly rejected "unconstitutional and undemocratic changes in government"-and the lack of criticism or sanctions on Thailand after the coup in 2014 suggest that political considerations may have priority over a strict application of the anti-coup norm (Woon 2016: 64-65).

\section{Conclusion}

This article breaks new ground in comparative regionalism by analyzing how the enlargement practices of different ROs are connected to broader discourses about regional standards of membership. It does so by analyzing normative crises the EC and ASEAN, in which the application of third states with troubled domestic politics challenged tacit assumptions about membership and held uncertain and potentially adverse consequences. In both cases, crisis led to an increased contestation of

\footnotetext{
${ }^{8}$ Cambodia was still allowed to participate in ASEAN meetings as a guest.
} 
established ideas about the constitutive foundations of the ROs and the introduction of new ideas about the internal political conditions for legitimate membership.

The European and Southeast Asian cases differed in the cognitive priors on which the discourses could draw. When confronted with the potential accession of Spain and Greece, previously tacit assumptions about the common democratic identity of the EC became explicitly debated. In Southeast Asia, the debates surrounding Myanmar's and Cambodia's possible membership fed upon the long-standing conjunction of domestic and regional resilience in ASEAN countries' strategic doctrine. This helps to explain the different outcomes in the RO's respective standards of membership. In Europe, the normative crisis ultimately resulted in the formalization of highly intrusive liberal democratic principles as a formal entry criterion in the Copenhagen criteria. ASEAN member states formulated and subsequently formalized an anti-coup norm geared towards ensuring domestic stability.

The study thus helps understand the dynamic and politically negotiated role of ideational factors in RO enlargement. The comparative approach makes the case that these changes are path-dependent in the sense of being shaped by regional normative preconditions. In addition, it acknowledges both the constitutive and the instrumental logic of enlargement action. Redefining the standard was a way of disciplining the accession candidates in line with the existing members' interests. In this sense, the European case echoes the normative mission of the original "standard of civilization" (Behr 2007; Nicolaidis et al. 2014), whereas ASEAN's cognitive priors were shaped by its members' desire to fend off interference and in fact reject any "civilizational" advances by outside actors - although, paradoxically, the resulting norm of domestic stability does have an intrusive element. Apart from projecting interests into the neighborhood, however, enlargement also hit home and transformed the constitutive foundations of the two ROs.

Despite this connection, enlargement practices are not a one-way street towards an evercloser collective identity. The disciplining power of the standard of membership naturally decreases once applicant states are admitted into the RO (Wiener 2004: 197-198). In the long run, newly acceded states may undermine the standard of membership and hence the regional norm community. In both regions, some if not most of the more recently acceded states value national sovereignty higher than the "old" member states (Anwar 2001; Thomassen and Bäck 2009). It is no wonder, therefore, that the debate about the finalité of the two organizations' boundaries is ongoing. Beyond this exploratory study, more cross-regional comparison is needed to foster our understanding of how historical conditions such as (post-)colonial relations translate into cognitive priors, and how these in turn influence RO enlargement practices. The interplay between enlargement practices and regional norms will remain an important object of study for foreseeable future.

Acknowledgements I wish to thank Joakim Berndtsson, Maria Eriksson Baaz, Anja Karlsson Franck, Thomas Risse, Johan Karlsson Schaffer, Frank Schimmelfennig, Fredrik Söderbaum, the anonymous reviewer and all the participants of the workshop on "Regions in Crisis" in Tübingen, 2-3 June 2016, for their invaluable comments on earlier versions of this article. Naturally, I take full responsibility for any remaining shortcomings.

Open Access This article is distributed under the terms of the Creative Commons Attribution 4.0 International License (http://creativecommons.org/licenses/by/4.0/), which permits unrestricted use, distribution, and reproduction in any medium, provided you give appropriate credit to the original author(s) and the source, provide a link to the Creative Commons license, and indicate if changes were made. 


\section{References}

Acharya A (2001) Constructing a security community in Southeast Asia: ASEAN and the problem of regional order. Routledge (Politics in Asia), London

Acharya A (2009) Whose ideas matter? Agency and power in Asian regionalism. Cornell University Press (Cornell Studies in Political Economy), Ithaca

Acharya A (2010) Asia is not one. J Asian Stud 69(4):1001-1013

Alatas A (1997) Opening statement at the 30th ASEAN Ministerial Meeting. Subang Jaya, 24 July. http://asean.org/?static_post=opening-statement-by-he-mr-ali-alatas-minister-for-foreign-affairs-ofindonesia. Accessed 12 March 2018

Amer R (1999) Conflict management and constructive engagement in ASEAN's expansion. Third World Q 20(5):1031-1048

Anwar DF (2001) ASEAN's enlargement: political, security and institutional perspectives. In: Than M, Gates CL (eds) ASEAN enlargement: impacts and implications. Institute of Southeast Asian Studies, Singapore, pp 26-44

ASEAN (1967) ASEAN Declaration. Bangkok, 8 August. http://asean.org/the-asean-declaration-bangkokdeclaration-bangkok-8-august-1967/. Accessed 12 March 2018

ASEAN (1976) Declaration of ASEAN Concord. Bali, 24 February. http://asean.org/?static post=declarationof-asean-concord-indonesia-24-february-1976. Accessed 12 March 2018

ASEAN (1991) Joint communiqué of the 24th ASEAN Ministerial Meeting. Kuala Lumpur, 26 June. $\mathrm{http}$ //asean.org/?static post=joint-communique-of-the-twenty-fourth-asean-ministerial-meeting-kualalumpur-19-20-july-1991. Accessed 12 March 2018

ASEAN (1997a) Joint Statement of the Special Meeting of the ASEAN Foreign Ministers on Cambodia, 10 July. http://asean.org/?static_post=joint-statement-of-the-special-meeting-of-the-asean-foreign-ministerson-cambodia-kuala-lumpur-malaysia-10-july-1997. Accessed 12 March 2018

ASEAN (1997b) Joint communiqué of the 30th ASEAN Ministerial Meeting. Subang Jaya, 25 July. http://asean.org/?static_post=joint-comminuque-the-30th-asean-ministerial-meeting-amm-2. Accessed 12 March 2018

ASEAN (1998) The 31st ASEAN Ministerial Meeting (AMM): joint communiqué. Manila, 24 July. http://asean.org/?static_post=joint-communique-the-31st-asean-ministerial-meeting-amm-manilaphilippines-24-25-july-1998. Accessed 12 March 2018

Behr H (2007) The European Union in the legacies of imperial rule? EU accession politics viewed from a historical comparative perspective. Eur J Int Rel 13(2):239-262

Birkelbach W (1961) Rapport fait au nom de la commission politique de l'Assemblée parlementaire européenne sure les aspects politiques et institutionnels de l'adhésion ou de l'association à la Communauté. In: Assemblée Parlementaire Européenne: Documents de séance 1961-1962, Document 122. https://www.cvce.eu/content/publication/2005/6/1/2d53201e-09db-43ee-9f80-552812d39c03 /publishable fr.pdf. Accessed 12 March 2018

Börzel TA, Risse T (2016) The Oxford handbook on comparative regionalism. Oxford University Press, Oxford

Bull H, Watson A (eds) (1984) The expansion of international society. Oxford University Press, Oxford

Business Times (Singapore) (1993) ASEAN urged to admit more members. 12 August, p 2

Buzan B (2014) An introduction to the English school: the societal approach. Wiley, Hoboken

Chalermpalanupap T (1999) ASEAN-10: meeting the challenges. Paper presented at the Asia-Pacific Roundtable, Kuala Lumpur. http://www.asean.org/asean-10-meeting-the-challenges-by-termsakchalermpalanupap/. Accessed 28 June 2017

Chin KW (1997) ASEAN: the long road to 'one Southeast Asia'. Asian J Polit Sci 5(1):1-19

Choo TL (1993) Focus on common threads, S-E Asian nations urged. The Straits Times, 23 February, p 17

Donnelly J (1998) Human rights: a new standard of civilization? Int Aff 74(1):1-23

Emmerson DK (1984) 'Southeast Asia': what's in a name? J Southeast Asian Stud 15(1):1-21

European Commission (1975) Greece and the European Community, Information 105/75, 455/X/75-F (E), Brussels. http://aei.pitt.edu/10229/1/10229.pdf. Accessed 12 March 2018

European Commission (1979) Opinion of 23 May 1979 on the application for accession to the European Communities by the Hellenic Republic. Official Journal of the European Communities 19 November (L 291):3

European Council (1978) Conclusions. Copenhagen, 20 April. http://www.consilium.europa.eu/media/20773 /copenhagen_april_1978_eng_.pdf. Accessed 12 March 2018 
European Parliament (1967) Résolution sur l'association entre le C.E.E. et la Grèce. Official Journal of the European Communities 10(103):2058

Fidler DP (2001) The return of the standard of civilization. Chi J Int L 2(1):137-157

Fierke KM, Wiener A (2005) Constructing international interests: EU and NATO enlargement. In: Schimmelfennig F, Sedelmeier U (eds) The politics of European Union enlargement: theoretical approaches. Routledge, Abingdon, pp 99-119

Frowein JA (1984) The European Community and the requirement of a republican form of government. Mich Law Rev 82(5/6):1311-1322

Goh CT (1991) Speech by the Prime Minister at the state banquet in honour of Mr Vo Van Kiet, Chairman of the Council of Ministers of the Socialist Republic of Vietnam. Ministry of Information and the Arts gct19911931, 31 October

Gong GW (1984) The standard of 'civilization' in international society. Clarendon Press, Oxford

Isberto R (1994) South-east Asia: 'One South-East Asia’ vision gains ground. IPS-Inter Press Service, 31 March

Jayakumar S (1997) Opening Statement By H.E. Professor S.Jayakumar Minister for Foreign Affairs of Singapore. Subang Jaya, 24 July. http://asean.org/?static_post=opening-statement-by-he-professorsjayakumar-minister-for-foreign-affairs-of-singapore. Accessed 12 March 2018

Jayanama A (1991) One Southeast Asia: the issues at stake. Vietnam Commentary 24 (November-December), pp 38-41

Jorgensen-Dahl A (1982) Regional organization and order in Southeast Asia. Macmillan, London

Kassim YR (1997) Waiting for normalcy. Business Times, Singapore, p 5

Katselli Proukaki E (2010) The problem of enforcement in international law: countermeasures, the non-injured state and the idea of international community. Routledge, London

Keene E (2002) Beyond the anarchical society: Grotius, colonialism and order in world politics. Cambridge University Press, Cambridge

Keene E (2014) The standard of 'civilization', the expansion thesis and the 19th-century international social space. Millenn J Int Stud 42(3):651-673

Khandeparkar U (1997) Singapore, Philippines defend ASEAN position. Reuter 6 October. http://www. burmalibrary.org/reg.burma/archives/199706/msg00179.html. Accessed 12 March 2018

Leuffen D, Schembera K, Schemel S (2016) Enlargement and Norm Emergence in Regional Organizations. A Theoretical Framework for the Comparative Analysis of ASEAN, Mercosur and EU. Paper for presentation at IPSA World Congress of Political Science, Montreal, 19-24 July. http://paperroom.ipsa. org/papers/paper_37674.pdf. Accessed 12 March 2018

Manners I (2002) Normative power Europe: a contradiction in terms? J Common Mark Stud 40(2):235-258

Narine S (2002) Explaining ASEAN: regionalism in Southeast Asia. Lynne Rienner, Boulder

Navari C, Green DM (eds) (2014) Guide to the English School in international studies. Wiley Blackwell, Hoboken (Guides to International Studies, Malden et al)

Nesadurai HES (2006) The Indo-Chinese enlargement of ASEAN: enhancing or undermining regional economic integration? In: Fort B, Webber D (eds) Regional integration in East Asia and Europe: convergence or divergence? Routledge (Routledge/Warwick Studies in Globalisation), Abingdon, pp 199-217

Nicolaidis K, Vergerio C, Fisher O, Viehoff J (2014) From metropolis to microcosmos: the EU's new standards of civilisation. Millenn J Int Stud 42(3):718-745

Ng E, Jegathesan M (1997) ASEAN defers Cambodia membership, vows to help find peaceful solution. Agence France Presse, Paris

O’Brennan J (2016) The EU and the Western Balkans: stabilization and Europeanization through enlargement? Routledge, London

Schimmelfennig F (2005a) Liberal community and enlargement: an event history analysis. In: Schimmelfennig F, Sedelmeier U (eds) The politics of European Union enlargement: theoretical approaches. Routledge, Abingdon, pp 172-197

Schimmelfennig F (2005b) The community trap: liberal norms, rhetorical action, and the Eastern enlargement of the European Union. In: Schimmelfennig F, Sedelmeier U (eds) The politics of European Union enlargement: theoretical approaches. Routledge, Abingdon and New York, pp 142-171

Sedelmeier U (2011) Europeanisation in new member and candidate states. Living Rev Eur Gov 6(1):1-52

Severino RC (2006) Southeast Asia in search of an ASEAN community: insights from the former ASEAN secretary-general. ISEAS Publishing, Singapore

Singapore Ministry of Foreign Affairs (1998) Comments by MFA spokesman on the outcome of consultations held by Minister for Foreign Affairs Prof. S Jayakumar with his ASEAN colleagues on the issue of the 
timing of Cambodia's admission into ASEAN. Ministry of Information, Communication and the Arts 1998120903, 8 December

Sjursen H (2002) Why expand? The question of legitimacy and justification in the EU's enlargement policy. J Common Mark Stud 40(3):491-513

Spandler K (2015) The political international society: change in primary and secondary institutions. Rev Int Stud 41(3):601-622

Stewart I (1997) Conflicting signals remain over Burma’s admission. South China Morning Post, 31 May, p. 12. http://www.burmalibrary.org/reg.burma/archives/199705/msg00630.html. Accessed 12 March 2018

Stivachtis Y (2008) Civilization and international society: the case of European Union expansion. Contemp Politics 14(1):71-89

Stroikos D (2014) Introduction: rethinking the standard(s) of civilization(s) in international relations. Millenn J Int Stud 42(3):546-556

Tan SS (2013) The making of the Asia-Pacific: knowledge-brokers and regional identity. Amsterdam University Press, Amsterdam

Thomas DC (2006) Constitutionalization through enlargement: the contested origins of the EU's democratic identity. J Eur Publ Policy 13(8):1190-1210

Thomas DC (2017) Beyond identity: membership norms and regional organization. Eur J Int Rel 23(1):217240

Thomassen J, Bäck H (2009) European citizenship and identity after enlargement. In: Thomassen J (ed) The legitimacy of the European Union after enlargement. Oxford University Press, Oxford, pp 184-207

Treaty Establishing the European Economic Community (1957). Rome, 25 March. https://www.ab.gov. tr/files/ardb/evt/1_avrupa_birligi/1_3_antlasmalar/1_3_1_kurucu_antlasmalar/1957_treaty_establishing _ eec.pdf. Accessed 12 March 2018

Ung Huot (1997) Opening Statement at the 30th ASEAN Ministerial Meeting. Subang Jaya, 24 July

Weatherbee D (2015) International relations in Southeast Asia: the struggle for autonomy, 3rd edn. Rowman \& Littlefield, Lanham

Wiener A (2004) Contested compliance: interventions on the normative structure of world politics. Eur J Int Rel 10(2):189-234

Woon W (2016) The ASEAN charter: a commentary. NUS Press, Singapore

Zhang Y (2014) The standard of 'civilisation' redux: towards the expansion of international society 3.0 ? Millenn J Int Stud 42(3):674-696 